\title{
PENGARUH SUNSET POLICY DAN TAX AMNESTY TERHADAP KEPATUHAN WAJIP PAJAK ORANG PRIBADI DALAM MELAKUKAN KEWAJIBAN PERPAJAKAN
}

\author{
Andjarwani Putri W ${ }^{1)}$ \\ Arief Budhi Dharma ${ }^{2)}$ \\ STIE Adi Unggul Bhirawa Surakarta \\ ariefbudhidharma1@gmail.com
}

\begin{abstract}
ABSTRAK
Penelitian ini bertujuan untuk menguji signifikansi pengaruh Sunset Policy dan Tax Amnesty terhadap Kepatuhan Wajib Pajak Orang Pribadi. Populasi yang digunakan dalam penelitian ini adalah Wajib Pajak Orang Pribadi yang terdaftar pada KPP Pratama Surakarta, dengan sampel yang digunakan dalam penelitian ini adalah 100 responden. Metode pengambilan sampel dengan cara convenience sampling dan pengambilan sampel menggunakan rumus slovin. Alat analisis yang digunakan meliputi uji validitas dan uji reliabilitas, uji normalitas, uji multikolinieritas, uji heteroskedastisitas, uji regresi linier berganda, uji koefisien determinasi $\left(\mathrm{R}^{2}\right)$, dan uji t. Hasil uji validitas menunjukkan bahwa semua pernyataan dinyatakan valid, uji Reliabilitas menunjukkan bahwa semua pernyataan dinyatakan reliabel. Uji asumsi klasik menunjukan bahwa data dalam penelitian ini terdistribusi secara normal, tidak terjadi multikolinieritas dan heterokesdesitas. Berdasarkan hasil penilitian regesi linier berganda membuktikan bahwa variabel sunset policy dan tax amnesty berpengaruh positif signifikan terhadap kepatuhan Wajib Pajak Orang Pribadi khususnya dalam kewajiban perpajakan.
\end{abstract}

Kata kunci : $\quad$ sunset policy, tax amnesty dan kepatuhan wajib pajak orang pribadi.

\section{PENDAHULUAN}

Peningkatan penerimaan negara dari sektor pajak sebagai salah satu sumber pembiayaan yang masih dimungkinkan dan terbuka luas, di dasarkan pada jumlah pembayar pajak dari tahun ke tahun yang diharapkan semakin banyak seiring dengan semakin bertambahnya jumlah penduduk dan kesejahteraaan masyarakat. Pajak merupakan penerimaan negara yang akan digunakan untuk pembiayaan umum dari segala kegiatan pemerintah, bahkan pajak juga merupakan salah satu tolok ukur dari keberhasilan perekonomi suatu negara.

Sebagai upaya untuk meningkatkan penerimaan di dalam negeri khususnya di bidang penerimaan pajak, maka mulai tahun 1983 pemerintah telah mengadakan Tax Reform (pembaharuan di bidang perpajakan).

Dengan adanya beberapa kali perubahan pada sistem perpajakan nasional tersebut ternyata tidak merubah ciri dan corak sistim pemungutan pajak yang berlaku, yaitu sistem "self assessment", yang berarti bahwa Wajib
Pajak diwajibkan menghitung, memperhitungkan dan membayar sendiri jumlah pajak yang seharusnya terhutang sesuai dengan ketentuan peraturan perundang-undangan perpajakan yang berlaku, sehingga penentuan besarnya pajak yang terhutang berada pada Wajib Pajak sendiri (Mardiasmo, 2001). Selain dari pada itu Wajib Pajak diwajibkan pula melaporkan secara teratur jumlah pajak yang terhutang dan yang telah dibayar sebagaimana ditentukan dalam peraturan perundang-undangan yang berlaku.

Indonesia memiliki berbagai permasalahan perpajakan antara lain penyelundupan pajak, rendahnya penerimaan pajak, dan rendahnya kepatuhan pajak. Pemerintah mulai membuat suatu program atau kebijakan dengan melihat kondisi tersebut. Permasalahan tersebut dapat diatasi dengan berbagai kebijakan, salah satunya dengan tax amnesty. Tax amnesty akhir-akhir ini menjadi isu yang santer dibicarakan di masyarakat, baik media masa ataupun media cetak. tax amnesty adalah program 
pengampunan yang diberikan oleh pemerintah kepada wajib pajak meliputi penghapusan pajak yang seharusnya terutang, penghapusan sanksi administrasi perpajakan, serta penghapusan sanksi pidana di bidang perpajakan atas harta yang diperoleh pada tahun 2016 dan sebelumnya yang belum dilaporkan dalam SPT, dengan cara melunasi seluruh tunggakan pajak yang dimiliki dan membayar uang tebusan.

(Andreoni, Brian, \& Jonathan, 1998) berpendapat bahwa tingkat kepatuhan wajib pajak hanya bisa dijelaskan dari aspek psikologi dan budaya seperti norma sosial, moral, patriotik, rasa bersalah dan malu. Dengan kata lain, walaupun wajib pajak dapat berbuat curang, tetapi mereka tidak akan mau melakukan kecurangan untuk aspek non ekonomi.

Berdasarkan latar belakang masalah yang telah diuraikan diatas, maka penulis merumuskan permasalahan sesuai dengan judul penelitian sebagai berikut :

1. Apakah penerapan Sunset Policy berpengaruh terhadap kepatuhan Wajib Pajak orang Pribadi dalam melakukan kewajiban perpajakannya?

2. Apakah penerapan Tax Amnesty.

Berdasarkan latar belakang dari perumusan masalah yang ada, tujuan yang hendak dicapai dari penelitian ini adalah untuk menguji :

1. Menganalisis sejauhmana pengaruh penerapan Sunset Policy berpengaruh terhadap kepatuhan Wajib Pajak orang Pribadi dalam melakukan kewajiban perpajakannya.

2. Menganalisis sejauhmana pengaruh penerapan Tax Amnesty berpengaruh terhadap kepatuhan Wajib Pajak orang Pribadi dalam melakukan kewajiban perpajakannya.

\section{METODOLOGI}

Varibel yang digunakan dalam penelitian ini adalah variabel independen yaitu Sunset policy dan Tax Amnesty satu variabel dependen yaitu kepatuhan Wajib
Pajak Orang Pribadi di Kantor Pelayanan Pajak Pramata Surakarta.

Jenis dan sumber data yang digunakan adalah data primer melalui kuesioner yang diperoleh dari responden secara langsung dengan metode survai di Kantor Pelayanan Pajak Pramata Surakarta.

Populasi dalam penelitian ini adalah seluruh Wajib Pajak Orang Pribadi yang terdaftar di Kantor Pelayanan Pajak Pratama Surakarta. Sampel dilakukan dengan metode Convenience Sampling dengan menggunakan rumus slovin

$$
n=\frac{N}{1+N(e)^{2}}
$$

Instrumen penelitian ini menggunakan skala Likert lima poin. Instrumen yang digunakan untuk mengukur semua variabel berjumlah 27 item pertanyaan. Sebelum dianalisis data, dilakukan uji kualitas data yaitu uji validitas dan reliabilitas. untuk mengetahui ada tidaknya penyimpangan dalam model regresi dilakukan uji asumsi klasik yaitu uji normalitas data, uji Multikolonieritas, Heteroskedastisitas. Uji hipotesis dalam penelitian ini akan diuji dengan menggunakan metode uji regresi linier berganda.

\section{HASIL PENELITIAN DAN PEMBAHASAN}

Data pada penelitian ini diperoleh dari hasil penyebaran kuesioner kepada 100 responden yang terdaftar sebagai Wajib Pajak Orang Pribadi di Kantor Pelayanan Pajak Pratama Surakarta. Responden berdasarkan pendidikan, responden dengan pendidikan SMA sebanyak 23 orang (23\%), responden dengan pendidikan S1 sebanyak 68 orang $(68 \%)$, responden dengan pendidikan S1 sebanyak 68 orang $(68 \%)$ sedangkan responden dengan pendidikan S2 hanya sebanyak 9 orang $(9 \%)$. Responden berdasarkan pekerjaan, responden dengan pekerjaan wiraswasta sebanyak 27 orang (27\%), responden dengan pekerjaan karyawan/pegawai sebanyak 73 orang (73\%). Responden berdasarkan pendapatan, responden dengan 
pendapatan sebesar 25-100 juta sebanyak 75 orang $(75 \%)$, responden dengan pendapatan sebesar 101-200 juta sebanyak 22 orang $(22 \%)$, responden dengan pendapatan sebesar 201-500 juta sebanyak 3 orang (3\%).

\section{Uji Instrumen}

\section{a. Uji Validitas}

Uji validitas digunakan untuk mengukur sah atau valid tidaknya suatu kuesioner. Suatu pernyataan dikatakan sah atau valid apabila corrected item-total correlation lebih besar dari $r_{\text {tabel }}$. Hasil pengujian validitas menunjukkan bahwa masing-masing pernyataan adalah valid.

\section{b. Uji Reliabilitas}

Reliabilitas dilakukan terhadap instrumen dengan menggunakan uji statistik cronbach'c alpha, apabila cronbach'c alpha > 0,60 maka instrumen yang digunakan reliabel. Hasil yang diperoleh dari pengujian reliabilitas instrumen penelitian menunjukkan nilai cronbach alpha masing-masing instrumen pernyataan menunjukkan nilai $>0,60$ sehingga masing-masing pernyataan tersebut reliabel.

\section{Uji Asumsi Klasik}

\section{a. Uji Normalitas}

Pengujian normalitas dilakukan pada nilai residual yang dihasilkan model regresi. Hasil perhitungan Kolmogorov-Sminov menunjukkan bahwa nilai signifikansinya ( $p$ value) sebesar $0,256>0,05$ maka residual model regresi berdistribusi normal.

\section{b. Uji Multikolinieritas}

Hasil uji multikolinieritas menunjukkan bahwa semua variabel independen yang digunakan dalam penelitian ini memiliki nilai tolerance $>0,10$ dan nilai variance inflation factor (VIF) < 10. Hal ini menunjukkan bahwa model regresi dalam penelitian ini tidak terjadi multikolinieritas antar variabel independen

\section{c. Uji heteroskedastisitas}

Hasil uji heteroskedastisitas menunjukan bahwa tidak terjadi heteroskedastisitas karena variabel independen tax amnesty mempunyai nilai signifikansi $>0.05$

\section{Analisis Regresi Linier Berganda}

Berdasarkan persamaan regresi linier dapat diketahui bahwa:

a. $\alpha=0,110$, artinya bahwa kepatuhan Wajib Pajak Orang Pribadi akan meningkat apabila tax amnesty mempunyai nilai nol atau tetap.

b. $\mathrm{B}_{2}=0,180$, menunjukkan bahwa tax amnesty berpengaruh positif terhadap Kepatuhan Wajib Pajak Orang Pribadi artinya apabila tax amnesty semakin ditingkatkan maka Kepatuhan Wajib Pajak Orang Pribadi akan semakin meningkat,

\section{Uji Hipotesis}

Pengujian hipotesis dilakukan dengan menggunakan uji $t$ untuk menguji suatu variabel independen dengan variabel dependen. Tingkat signifikansi yang digunakan adalah 0,05 maka dapat disimpulkan sebagai berikut :

Hipotesis 1 tax amnesty terhadap kepatuhan Wajib Pajak Orang Pribadi menghasilkan nilai signifikansi sebesar $0,000<0,05$, maka $\mathrm{H} 0$ ditolak. Artinya bahwa tax amnesty berpengaruh signifikan terhadap kepatuhan Wajib Pajak Orang Pribadi di Kantor Pelayanan Pajak Pratama Surakarta. 


\section{a. Uji uji koefisien determinasi $\mathbf{R}^{2}$}

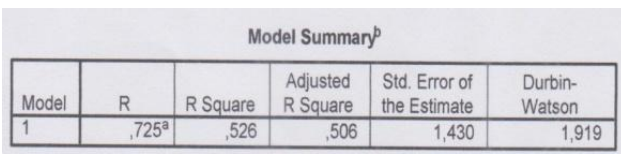

Hasil uji koefisien determinasi $\mathrm{R}^{2}$ diperoleh nilai Adjusted $\mathrm{R}^{2}$ sebesar 0,506 yang berarti variabel dependen yang dapat dijelaskan variabel independen sebesar $50,6 \%$ hal ini berarti variabel independen meliputi sunset policy dan tax amnesty mempengaruhi kepatuhan Wajib Pajak Orang Pribadi sebesar 50,6\% sedangkan sisanya sebesar 49,4\% dipengaruhi oleh variabel lain yang tidak diteliti dalam penelitian ini.

\section{KESIMPULAN DAN SARAN}

Berdasarkan analisis yang sudah dilakukan dapat disimpulkan hal-hal sebagai berikut :

1. Hasil uji regresi linier berganda menunjukkan bahwa sunset policy, tax amnesty berpengaruh signifikan terhadap kepatuhan Wajib Pajak Orang Pribadi di Kantor Pelayanan Pajak Pratama Surakarta.

2. Hasil uji koefisien determinasi $\left(\mathrm{R}^{2}\right)$ menunjukkan nilai adjusted $\mathrm{R}^{2}$ sebesar $50,6 \%$ artinya sunset policy, tax amnesty memberikan kontribusi pengaruh terhadap kepatuhan Wajib Pajak Orang Pribadi sebesar 50,6\% sedangkan sisanya sebesar 49,4\% dipengaruhi oleh variabel lain yang tidak diteliti dalam penelitian ini.

Saran yang diberikan oleh peneliti yaitu sebagai berikut :

1. Sebaiknya pelayanan mulai memperhatikan one stop service yaitu pelayanan melalui satu pintu atau satu loket sehari selesai sehingga dapat efisiensi waktu, serta fasilitas Fotocopy, materai dan alat penunjang lainnya yang disedia didalam kantor pelayanan pajak pratama sehingga wajib pajak dapat dengan mudah melengkapi data yang dibutuhkan.

2. Adanya tax amnesty kantor pajak dapat menggali potensi-potensi objek pajak baru sehingga dapat meningkatkan pendapatan negara.

3. Bagi peneliti berikutnya tidak hanya menggunakan metode kuesioner namun dapat menambahkan metode interview secara langsung kepada responden agar responden memberi jawaban yang benar-benar diliputi kesungguhan dan keseriusan, serta peneliti lebih terlibat dalam proses penelitian dan dapat memperluas objek variabel seperti peraturan pajak dan peraturan pemerintah yang baru, tidak hanya Wajib Pajak Orang Pribadi tapi juga ke wajib pajak badan bahkan bisa ke wajib pajak luar negeri.

\section{DAFTAR PUSTAKA}

Andreoni, J., Brian, E., \& Jonathan, F. (1998). Kepatuhan Pajak. Journal of Economic, 36, 818-860.

Fikriningrum, W. K., \& Syafruddin, M. (2012). Analisis faktor-faktor yang mempengaruhi Wajib Pajak Orang Pribadi dalam memenuhi kewajiban membayar pajak (Studi Kasus Pada Kantor Pelayanan Pajak Pratama Semarang Candisari). Journal of Accounting, 1, 1-15.

Fuadi, arabella oentari, \& Mangoting, Y. (2013). Pengaruh Kualitas Pelayanan Petugas Pajak, Sanksi Perpajakan dan Biaya Kepatuhan Pajak Terhadap Kepatuhan Wajib Pajak UMKM. Tax \& Accounting Review, 1.

Ghozali, Imam. (2012). Aplikasi analisis multivariante dengan program IBM SPSS 20: Penerbit Universitas Diponegoro.

Jatmiko, agus nugroho. (2006). Penngaruh sikap wajib pajak pada pelaksanaan sanksi denda, pelayanan fiskus dan kesadaran perpajakan terhadap Kepatuhan Wajib pajak ( Studi 
Empiris Terhadap Wajib Pajak Orang Pribadi di Kota Semarang ). Universitas Diponegoro.

Jotopurnomo, C., \& Mangoting, Y. (2013). Pengaruh Kesadaran Wajib Pajak, Kualitas Pelayanan Fiskus , Sanksi Perpajakan, Lingkungan Wajib Pajak Berada terhadap Kepatuhan Wajib Pajak Orang Pribadi di Surabaya. Tax\&accounting Review, 1, 50-54.

Kiryanto (2000). Analisis Pengaruh Penerapan Struktur Pengendalian Intern Terhadap Kepatuhan Wajib Pajak bada Dalam Memenuhi Kewajiban Pajak Penghasilannya. EKOBIS, Vol. 1 No. 1, p. $41-52$

Mardiasmo. (2011). Perpajakan. Yogyakarta: Andi.

Mutia, S. P. T. (2014). Pengaruh Sanksi perpajakan, Kesadaran perpajakan, Pelayanan fiskus, dan Tingkat pemahaman terhadap Kepatuhan Wajib Pajak Orang Pribadi. Universitas Negeri Padang.

Ngadiman, \& Huslin, D. (2015). Pengaruh Sunset policy, Tax Amnesty, Dan Sanksi Pajak Terhadap Kepatuhan Wajib Pajak ( Studi Empiris di Kantor Pelayanan Pajak Pratama Jakarta Kembangan ). Jurnal Akuntansi, XIX (02), 225-241.

Nugroho, adi rahman. (2012). Faktorfaktor yang mempengaruhi kemauan untuk membayar pajak dengan kesadaran membayar pajak sebagai variabel intervening (Studi Kasus Wajib Pajak Orang Pribadi Yang Melakukan Pekerjaan Bebas Yang Terdaftar Di KPP Pratama Semarang Tengah Satu). skripsi. Universitas Diponegoro.

Pancawati, H., \& Nila, Y. (2011). Faktorfaktor yang mempengaruhi kemauan membayar pajak. Dinamika Keuangan Dan Perbankan, 3, 126-143.

Rohmawati, A. N., \& Rasini, N. K. (2012).
Pengaruh Kesadaran, Penyuluhan, Pelayanan, dan Sanksi Perpajakan pada Kepatuhan Wajib Pajak Orang Pribadi. Universitas Udayana.

Setyonugroho, H. (2012). Faktor-faktor yang mempengaruhi kemauan untuk membayar pajak Wajib Pajak Orang Pribadi di KPP Pratama Surabaya Tegalsari. Skripsi. Sekolah Tinggi Ilmu Ekonomi Perbanas Surabaya.

Soemarso S.R. (1998). Dampak Reformasi Perpajakan 1984 Terhadap Efisiensi Sistem Perpajakan Indonesia. Ekonomi dan Keuangan Perpajakan di Indonesia, Vol. XLVI No. 3, p. 333 368

Suandy, E. (2014). Hukum Pajak (6th ed.). Jakarta: Salemba Empat.

Sugiyono. (2012). Statistik untuk Penelitian. Bandung: Penerbit CV Alfabeta.

Suyatmin. (2004). pengaruh sikap wajib pajak terhadap kepatuhan wajib pajak dalam pembayaran PBB. Tesis. Universitas Diponegoro.

Uma Sekaran (2006). Metodologi Penelitian untuk bisnis. Penerbit Salemba Empat.

Utami, S.R., Andi, dan Soerono, A.N. (2012). Pengaruh Faktor-Faktor Eksternal Terhadap Tingkat Kepatuhan Wajib Pajak Di Lingkungan Kantor Pelayanan Pajak Pratama Serang. Simposium Nasional Akuntansi XV, Banjarmasin.

Tiraada, tryana A. . (2013). Kesadaran perpajakan, Sanksi Pajak, Sikap Fiskus terhadap kepatuhan WPOP di Kabupaten Minahasa Selatan. Jurnal Emba, 1, 999-1008.

Widayati, \& Nurlis. (2010). faktor-faktor yang mempengaruhi kemauan untuk membayar pajak wajib pajak orang pribadi yang melakukan pekerjaan bebas. Simposium Nasional Akuntansi XIII Purwokerto, 1, 1-23. 